\title{
An Analysis of the Anglophone Political Demands in Cameroon from 1961 To 2018
}

\author{
THIERRY ROLAND TABI AGBOR \\ MSc, Political Science and International Relations Program, Social Sciences Institute, Istanbul Aydin University
}

\begin{abstract}
This paper discusses the origin, development and current situation of the Anglophone crisis going on in Cameroon. It covers the period of pre-independence, independence and post independence of Cameroon's status quo. The partition of Cameroon came in with a positive spirit as it galvanized the mind of the fellow subjugated people, thus made Cameroon people to revolt and stand against all the injustices perpetrated by the foreign powers. Therefore, separate nationalist movements took place in the territory with main objectives, the restoration of Anglophone sovereignty. The restitution of the people's identity and way of life in all sociocultural domains of the local people, for they found their traditions and customs being changed and jeopardized. Taking a review of the area being researched, the current crisis situation in the English-speaking part of Cameroon as the result of a series of several strikes with no positive reaction from the government. These strikes first turned into premature demonstrations for a different form of state and against the marginalization of the English-speaking population of the country. This therefore effected to the above main finding of this topic such as the breach of some clauses of the Foumban Constitutional conference of 1961, marginalization of Southern Cameroonians, lack of developmental projects in Southern Cameroon, denial by the central government to listen to the Anglophone lawyers and teachers and lastly, President Paul Biya's 36 years of reign. It is important to highlight that these main findings are the main causes of this crisis on going, reason why a deeper thought is being considered so as to perfectly understand the root causes of this consciencism by the Anglophone people. The results of this crisis are devastating for it has led to a gross loss of in terms of revenue and loss of innocent lives. In 2018, contributions from various scholars with opinions on the form of the state emerged and was launched by professional organizations and associations of civil society which were divided but had the same perspectives, Whether federation or secession could replace the current status quo of the two joined Cameroons. Trade union leaders and activists want a federal state so as to end the crisis but for the regime in place, Cameroon is united, one and indivisible, and changing the form of the unitary State ${ }^{1}$, which is centralized would be impossible, therefore accounting the presence of the on going crisis in the two Anglophone regions of Cameroon.
\end{abstract}

Keywords: Anglophones ${ }^{2}$, Cameroon, Crisis, Francophone, Secession, Unitary state.

DOI: 10.7176/PPAR/9-3-05

Publication date:March $31^{\text {st }} 2019$

\section{INTRODUCTION}

Although Cameroon has been known to be one of the most peaceful and stable countries in the sub-region of Central Africa and Africa as a whole. It started facing issues of Boko Haram in March 2014. This pertinent issue slowly transformed into serious threats especially in the Northern part of Cameroon and gradually plagued the entire country with a feeling of insecurity. Over time, this had been the first and only threat which was confronted by the military until October 2016 in Bamenda when the Anglophone crisis emerged. This crisis began with few demands but the attitude of the central government made the demands to escalate in the present crisis. This situation goes a long way to say that out of the 10 regions of Cameroon, the central government is in control of just eight regions, two of the regions which belongs to the Anglophone speakers whom are bent on the restoration of their rights as outlined in Foumban constitution of 1961. It is clear that the results of the disrespect of this union between French and English Cameroon led to what is today called the Anglophone crisis which until now has no concrete remedies for the restoration of peace and the fate of the Anglophones under President Paul Biya's regime for the past two years now.

Taking a closer look at events of the year 2016 in the month of October, it could be affirmed that a good number of resistances and disagreements emerged in various sectors of Cameroon. These demonstrations replicated to the present political crisis, which has plagued the country. This situation had created the feeling and the need for many interrogations in the mind of scholars and that of the local population in regards to the various ways of governance through a centralized system that has been put in place. Cameroon is divided into ten regions and out of the ten regions; the Anglophone citizens populate two. These two regions constitute 16,364 square kilometers of the country and eight regions to the French speaking section, giving a total of 475,442

\footnotetext{
${ }^{1}$ A unitary state is a state governed as a single power in which the central government is ultimately supreme.

${ }^{2}$ consisting of or belonging to an English-speaking population especially in a country where two or more languages are spoken
} 
square kilometers with 25 million inhabitants, 5 million inhabitants in the Anglophone region and approximately 20 millions inhabitants are Francophones of French Cameroon (World population review, 2018). The present crisis could be said to have resulted from the careless and repressive attitudes of the government towards their Anglophone citizens who only wanted to be listened, and for their besieged situation to be taken into consideration. This incautious attitude by the government led to a sudden re-awakening in the minds of the Anglophones in the perspective of trust between one another and especially the central government to the extend that this self determination goes a long way to put the question of the return to federalism or secession as the two possible envisage options contemporarily as a matter of fact.

On January 1, 1960, the former Cameroon, then under French trusteeship, acceded to independence and witnesses the birth of the Republic of Cameroon. This newly independent country was formed in a very short period of fifty-eight years. From July 14, 1884, the day Gustav Nachtigal hoisted the German flag in Douala ${ }^{1}$ in 1918, when the Germans had to abandon Cameroon, this territory was under Berlin protectorate. Germany renounces all its rights over Cameroon by ratifying the Treaty of Versailles ${ }^{2}$ of June 28, 1919. Article 119 of this treaty stipulates that: "Germany renounces in favor of the principal allied powers and associated with all its rights and titles on his Outros possessions" (Fanso, 1989).

In a brief perspective, Britain and France divided Cameroon on $10^{\text {th }}$ July 1919. They administered it on behalf of the League of Nations (LON). Talking about the mandate system, Britain administered the western part of the country (about one fifth of the territory) and France the eastern part (about four fifth of the territory). From 1939 to 1946, Cameroon under French mandate, responding to the call of General De Gaule, participated in the Second World War (Fanso, 1989).

Present day Anglophone or English Cameroon is the Northwest and Southwest regions geographically. The cry of the Anglophones, their need for self governance and the need to take over their fate in the sphere of governance and development has been given scholarly attention by political scientists and historians. These scholarly attentions are in different forms of writings either through articles, journals, magazines, research papers and books. They all converged into the same main aspects, that of the Anglophones need for a change of the form of the state and a perfect rehabilitation of both previously colonized states. Some of the works focuses on the role played by secessionists groups in regards to the current situation, federalist groups, factors that led to the spark of this Anglophone problem and the like. However, this paper will focus on an analysis of the demands made by the Anglophones to the central government of Cameroon. In addition, the most important aspects that will be outlined in this piece of work is to demonstrate the nature and scope under which these demands emerged and how they have been able to apply their convictions so far, to demand a change of the status quo taking into consideration that Anglophones have come to be aware of the fact that there is no bright future under the canopy of Francophone governance which is not encompassing for them. From the tutelage of the United Nations to the Republic of Cameroon, with the establishment of the United Nations (UN) in 1945, the two mandated territories came under the control of the Trusteeship Council, which had to ensure their aspirations towards independence and total sovereignty. This paper focuses on the relationship between the demands made by the Anglophones citizens and the reply made by the central government in regards to these demands posited in practice. It is a reflection on the impact of structuring this symbolic space for taking the floor to reflect and decide on the management of country's issues and a political change that has taken place in Cameroon since the end of the 1980s. This interrogation aims to provide proof that the Cameroonian political transition carries a double dynamic: as a crisis, it is envisaged in the sense of Michel Dobry (1995) and Georges Balandier (1989), both as a decomposition and reconstruction. Having explained how this union came about from the partition of 1916 and unification of Cameroon until today's present crisis, it creates a number of vital questions; has the government taken any initiative towards this pertinent situation? Who are the main activists and propagators of this crisis? What are their demands? What has been said or done by international organizations of the world admitting the fact that human rights are being violated and defied in the course of this crux? In response to these interrogations, this thesis will outline a number of answers relying on research work reviews, current information surrounding the crux and current ideas of scholars conducted through interviews, newspapers and journal articles.

Taking a review of the area being researched by Nkoyock (2017) describes the current crisis situation in the English-speaking part of Cameroon as the result of a series of several strikes with no positive reaction from the government. These strikes first turned into premature demonstrations for a different form of state and against the marginalization of the English-speaking population of the country. In his work, Nkoyock (2017) denounces the violation of the Foumban constitutional conference ${ }^{3}$ and the loss of benefits, favors and privileges granted to

\footnotetext{
${ }^{1}$ Douala (German: Duala) is the largest city in Cameroon and its economic capital. It is also the capital of Cameroon's Littoral Region.

${ }^{2}$ Treaty of Versailles, peace document signed at the end of World War I by the Allied and associated powers and by Germany in the Hall of Mirrors in the Palace of Versailles, France, on June 28, 1919; it took force on January 10, 1920.

${ }^{3}$ On 5 May 1960, Ahmadou Ahidjo became president. On 11 February 1961, a plebiscite organised by the United Nations was held in the British controlled part of Cameroon (British Northern and British Southern Cameroons). ... On 14 August 1961, the federal constitution was adopted, with Ahidjo as president.
} 
them in the days of federalism. This conference was the most delicate and most precise arena to amalgamate both officials of the two regions joined, to discuss how they will live as a joint union. A number of issues had to be solved through collective peaceful and pragmatic ways, fully implemented and respected in the entire territory so that none of the above protagonists will feel defied and detached of their sovereign rights. One of the many points raised at this conference was the official language to be adopted. It should be clearly noted that each of these states had their vernacular as local people of a region but could not be implemented as official languages, reason being that with the wide nature of tribes and villages in the regions, it was difficult to adopt a single vernacular since all these villages as well had different dialects. Therefore, the best choice was English and French; therefore, the country had English and French as official languages at the end of the conference. This simply meant that both languages had equal status, one language was not superior to the other. English being the official language of the British and French being the official language of the French. These two languages had to be adopted so as to solve the problem of reunification at the Foumban conference because one of the two languages could not be adopted, for it was even impossible and not possible (Mbangwana, 2004).

In 1912, the Germans drew the first map of Cameroon and a new nation was born named Kamerun. Modern Cameroon is therefore, a German creation. these nations were set close to one another and existed linearly within the German created Kamerun even though there were nationalist and resistant movements that came up in the territory, but were suppressed (Ardener, 1968). In 2018, opinions on the form of the state, launched by professional organizations and associations of civil society are divided. The trade union leaders and activists want a federal state so as to end the crisis. For the regime in place, Cameroon is united and indivisible, and changing the form of the unitary State, which is centralized, would be impossible (Nkoyock, 2017).

For some supporters of a Republican state, federalism would be a back-pedaling and return to this stage ${ }^{1}$. It would be a way of opening the door to secessionism. Others emphasize the importance of federalism, bringing hope for democracy, good governance and development. It is important to point out this relevant historical fact on the current issue of the Anglophone crisis, which goes back to the history of Cameroon, former German colony. Cameroon is a German creation that began in 1884, date of the signing of the German-Douala Treaty. The Germans stayed in Cameroon for 32 years. They leave the "Kamerun" after their defeat at the end of the first world war. The territory Cameroon is then placed under the tutelage of France and the United Kingdom. The genesis of the Anglophone problem in Cameroon as shall be analyzed in the following chapters takes its origins to the partition of the territory by Britain and France in 1916. This unequal division of the territory between the two powers with France getting the lion's share sowed the seeds of future problems of administration since the condominium itself failed, thus; the emergence of the reunification of Cameroon with an Anglophone minority and a francophone majority (Awasum, 1998).

Following from the partition of the territory ${ }^{2}$, it is important to make a review of the area being researched by illustrating the role-played by the British and the French as they embarked on foreign - domestic policies that shaped and influenced today's current circumstances. These policies were especially their way of rule, how the people should be administered as new people with new colonial masters. This policy came with some positive and a lot of negative outcomes as the people felt to have lost their identity as a sovereign tribe, especially in the cultural perspective. The partition of Cameroon came in with a positive spirit for it galvanized the mind of the fellow subjugated people, thus Cameroon people to revolt and stand against all the injustices perpetrated by the foreign powers. Therefore, separate nationalist movements took place in the territory with main objectives, the restoration of Anglophone sovereignty. The restitution of the people's identity and way of life in all sociocultural domains of the local people, for they found their traditions and customs being changed and jeopardized. They were highly motivated and esteemed the necessary need in aspiring for the recreation of their nation as it used to be before the annexation period (Kofelekale, 1980). There are many federalist states such as Switzerland, Germany, Austria, Belgium, the States United, India, Australia, Nigeria, Sudan (Dejo, 2017). Cameroon also has a federal system with similar process and governing measures as states that have united to form one nation (Huc, 2015).

\section{The Colonial Era, The Independence period and the Reunification of Cameroon}

Just like most countries in Africa and in the world in a general perspective, Cameroon is a colonial product. It has its specificities and complexity, which are quite difficult to comprehend. Cameroon with no doubt is one of only a few countries in Africa to have had three colonial masters, Germany, France and Britain respectively and has serpentine through Anglo-French Trusteeship, Federalism and the unitary state, to what is today just the state. Prior to the German annexation of Cameroon on the $11^{\text {th }}$ July 1884 , Cameroon consisted of a wide range of tribes, in addition, it was a diverse cultural nation with about 250 tribes such as the Bamilekes, the Duala's, the Gbayas, the Bamums, the Tikars, the Nso, the Mbos and the like. Each of this tribes before any spheres of

\footnotetext{
${ }^{1}$ Before 1972, Cameroon was a federal state, thus French and English Cameroon being two different states governed autonomously

${ }^{2}$ Division of Cameroon by the French and the British in 1918
} 
foreign interference into Cameroon's social and cultural life were socio-culturally organized and stable. The first and untimely inhabitants of Cameroon were with no doubts the Pygmies, who till today occupy the thick forest of the East and Southern regions of Cameroon. In the 1770s, the Western Sahel indigenes of Cameroon repressed and overwhelmed the non-Muslim people of the northern regions of Cameroon, reason why the Muslims, through a series of jihads, inhabit today a majority of the northern part of Cameroon.

\section{The Colonial Era 1884-1916}

Atanga (2011) claimed that, the key to the understanding of contemporary politics in the Cameroons lies in the proper grasp of its colonial history and its extra-ordinarily rich cultural, ethnic, economic and political diversity. He continues by saying that, the Federal Republic of Cameroon came into being in 1961 as the first "bilingual" federation in Africa, bringing together peoples whose separate colonial experiences provided stark contrasts not only in language, law, administration, and education, but equally in such matters as political style and expectations. In this chapter, one will plunge into a serious analysis how this colonial factors and the partition of Cameroon evolved and surely but gradually shaped the history of Cameroon in its peculiar contemporary context. In the subsequent paragraphs, one will focus on the course of this colonial era, what are the main reasons for such an interest in uncivilized and traditional nations? How colonization took place and what were the major phases of this period, what modifications occurred due to this era and what were the Cameroonian elites' sentiments and appreciation in regards to this imperial attitude? Therefore, all these aspects will go a long way to portray how the Anglophone crisis had been sewn since from the period of European interest in Cameroon with main protagonists as the Germans, British and the French who till today play a major role in Cameroon political affairs.

Furthermore, Nicodemus (1998, p. 9) further claims that, the beginning of the Anglophone issues in Cameroon originated from the partition of the territory by the British and French in 1916 proceeding from the end of the Second World War, which marked an end of German subjugation in the territory. Following the denouement of the 17th and early 18th centuries, the Dutch, Portuguese, French, English, Swedish and Danish were active at the coast of Cameroon as slave merchants. By the start of the 19th century Calabar, Douala and Bimbia on the Rio dos Cameroes and Rio del Rey was renound slave shipping ports on the Bight of Biafra along the Ambas Bay. A majority of captured slaves in Cameroon were transported via these vital ports, which also served as economic frontiers for the proliferation of economic activities (Eyongetah and Brain 1974: 55; Le Vine 1964: 17; Johnson 1970a: 69).

Alfred Saker who was a prominent missionary ${ }^{1}$ at that time and a great religious activist founded a settlement for free slaves in 1858 on this bay later named Victoria, and was later proclaimed capital of the Albas Bay protectorate in 1884 .

After the abolition of slave trade by the British in the territory with all its ills and defective activities propagated, she opened a stationed group of troops at Fernando Po, which is contemporarily called Equatorial Guinea sub so as to regulate and monitor slave shipments from the Bights of Benin and Biafra in 1827. All these activities as vividly portrayed will go along way to demonstrate British interest in Cameroon and her need to consolidate her protectorate.

In addition, the British later became the dominant force along the Nigeria and Cameroons coast (Le Vine 1964). They used this advantage to encourage British trading firms to set up trading posts in the Cameroon's coast, for it was a lucrative area for economic activities. It was during this era that the use of Pidgin English began to spread as a vital alternative to language barriers (Eyongetah and Brain 1974: 56).

\section{The Partition of Cameroon 1916}

According to Osuntokun (1974), it is important to outline that the partition of Cameroon came as a result of the end of the First World War were Cameroon was involved as German protectorate. During the outbreak of the First World War in 1914, Kamerun's colonial master, Germany, was accused of having caused the war. As the War progressed in Europe, the Germans defeated one European power after another includes France, Belgium and Russia. For it was of no doubt that the Germans were economically and militarily ready for such conflicts. The Allied Powers, particularly, Britain and France, who were earlier defeated in Europe, decided to extend the war to Africa and targeted the German colonies of Togoland, Tanganyika ${ }^{2}$, German South West Africa and Cameroon. It has been argued, "it was territorial covetousness rather than the question of imperial security that led France and Britain to attack German colonial empires." In the case of Cameron, Britain had always wanted to regain "all the territories which she had lost to Germany by default in the period of the scramble of Africa" (Fischer 2014).

Territories believed to contain the richest soil and to be among the most productive areas of the world,

\footnotetext{
${ }^{1}$ A missionary is a member of a religious group sent into an area to proselytize or perform ministries of service, such as education, literacy, social justice, health care, and economic development.

${ }^{2}$ Tanganyika was a territory administered by the United Kingdom from 1916 until 1961 and today called Tanzania.
} 
(Calvert, 1917) with the most potential economic developmental capabilities. The British Government did not forgive Germany for by passing annexation her and annexing Cameroon and Britain herself for her own blunder in giving to Germany during the boundary negotiations those healthy areas on Nigeria's eastern frontiers, suitable for British servants in West Africa. Britain also accused Germany of violating the Belgian Neutrality Pact and became actively involved in the war. It was a British tradition that "in a major war against a European power possessing territories overseas, such territories should be occupied by British forces as soon as practical" (Fanso, 1989) in order to act as a bargaining chip after the war.

This War in Cameroon lasted from 1914 to 1916 and the joint Anglo-French forces defeated and ousted the Germans from the territory. Within this period, the Anglo-French forces attempted a joint administration (condominium) that was not very effective however. The result was the Anglo-French partition of the German Kamerun on March 4, 1916 (Elango, 1987).

\section{Independence and Reunification Period in Cameroon}

According to Stark (1976), following from the partition of the territory, the British and the French embarked on foreign- domestic policies. These policies were especially their way of rule, how the people should be administered as new people with new colonial masters. This policy came with some positive and great negative outcomes as the people felt to have lost their identity as a sovereign tribe, especially in the cultural perspective. The partition of Cameroon came in with a positive spirit for it galvanized the mind of the fellow subjugated people, thus Cameroon people to revolt and stand against all the injustices perpetrated by the foreign powers. Therefore, separate nationalist movements took place in the territory with the main objective. The restitution of the people's identity and way of life in all socio-cultural domains of the local people, for they found their traditions and customs being changed and jeopardized. They were highly motivated and esteemed the necessary need in aspiring for the recreation of their nation as it was before the annexation. The Cameroon people through a "Pan- kamerun" nationalist idea were born with a good number of internal and external factors that paved the way for the fight of Cameroon's independence and reunification. It should be noted that, this was the most crucial period in Cameroon history, for it has shaped the nature and form of the Cameroon present state of politics through this joint fight and reunification by the two sovereign nations which is today called the Anglophone problem. A few of this internal factors that necessitated the need for a self affirmation and independence was the inhumane and hard colonial policies inflicted on the people in their own territory. This was the case for Anglophone and French Cameroon, supervised and administered by foreign personnel's, for they forced the people to work in their plantations under deplorable conditions with almost no wages in return, public flogging of respected natives due to disobedience of certain rules and regulations determined by the foreign power officials in Cameroon.

In addition, external factors such as the Nigerian nationalist movements that led to the independence on October 1960, the Brazzaville Conference and the Atlantic charter that proved the need for self-determination all influenced both the English and French Cameroon to fight for their rights separately to free themselves from this bondage (Kofelekale, 1980).

Following the UPC's ${ }^{1}$ movements in the entire region of French Cameroon, they demonstrated and made their ideas very clear in the entire territory of Cameroon, thus their need for immediate independence of French Cameroon and the subsequent immediate reunification with British Cameroon, with no foreign intermediation in their domestic affairs. This was the first step and most important step towards the granting of independence, selfdetermination and non-dependence. On the 13th July 1955, the UPC's actions became more and more threatening as it was later banned and deterred from any further actions of seceding and this cause the division of the party for many of the party leaders to escape and seek refuge in the Anglophone British Cameroon were French territorial competence was limited. Though this violent movement were crushed while fighting for their rights, it led to the gradual process of independence with constitutional improvements and elections were held in French Cameroon as it led to the creation and appointment of Andre-Marie Mbida as he became the first Prime Minister in May 1957 though he later had divergent views with the French authorities and French Cameroonians themselves and force to resign one year later on February 1957 (Wanki, 2015).

Furthermore, Ahmadou Ahidjo ${ }^{2}$, another main political actor in French Cameroon who acted as assistant prime minister and minister of interior under the previous government led by Mbida succeeded him. Ahidjo was well approved by he French because he was there to somehow maintain that linear relationship with the French government, as his ideas were that of immediate independence for Cameroun, immediate reunification with British- administered Cameroon and a liaison with France. Ahidjo being favored by France requested the transmission of full powers to the Cameroonian people, thus the end of French rule and administration in Cameroon. (Fanso, 1989) This was effected by France requesting the end of the trusteeship disposition in the

\footnotetext{
${ }^{1}$ Union des population Camerounaises, political party

${ }^{2}$ Ahmadou Ahidjo. Ahmadou Ahidjo (1924-1989) was the first president of the Federal Republic of Cameroon and one of the most influential leaders of the French-speaking African states.
} 
league of Nations Covenant of article 22 and 23 as it was voted in the United Nations General assembly and trusteeship council on the 12th to 14th March and on the 1 January 1960, former French protectorate was granted full national independence, territorial integrity and national sovereignty as this was reflected in the change of name to "La Republique Du Cameroun" with Ahmadou Ahidjo as prime minister and later on president of the Country (Ngoh, 2004).

Moreover, in the perspective of nationalism and the need of total independence from European forces, the other section of Cameroon, which was divided and claimed by the British embarked as well on serious and exploitative actions that did not please the natives of the region, thus they found the need to be granted their full autonomy as a nation. In order for this to be realized, they formed nationalists movements headed by various native rulers who had divergent but precise ideologies on how the country should be administered, therefore, they were divided into four mainstream; one of this political activist group were the autonomists, who preferred and visualized Southern Cameroon as an autonomous region of Cameroon with Nigeria. Another proponents called the secessionist wanted the territory to separate from Nigeria and gain independence as a separate political entity. This third were the reunificationist, who wanted secession from Nigeria but immediate reunification of British and French administered Cameroons and the immediate independence of Cameroon. The last were the Foncharians, led by john Ngu Foncha, who wanted secession from Nigeria and unification of British Northern and Southern Cameroons and subsequently reunification with the French administered territory La Repubique Du Cameroun (Chem-Langhee and Njeuma 1980).

A good number of Southern Cameroonians wanted separation without any further reunification either with Nigeria or with La Republique du Cameroun. This ideology was mostly propagated by native rulers who were very influential the time and did not have any political family. The granting of independence in Anglophone Cameroon was very complicated reason being that during the partition, Britain administered the South west and North west regions of Cameroon into one, therefore in the course of granting independence, there was the issue on what would be the accurate question to be written on the electorate for the 11 February plebiscite (Ngoh, 1990) Due to the seriousness of the matter, the UN had to intervene so as to ensure peaceful settlement on the matter. She therefore drafted a choice either by gaining independence with integration with Nigeria or Reunification with French Cameroun (Pungong, 1993).

The people in reply to this decision denigrated the UN imposition because forth it was more of a nature on where they will feel accepted and much comfortable in the administration of the territory as one people, so they felt that the question was not accurate enough for they preferred being autonomous without any further integration with neither La Republique nor wit Nigeria for there was no third and fourth option to select. The plebiscite question went thus; do you wish to achieve independence by joining the independent Federation of Nigeria? Or Do you wish to achieve independence by joining the independent Republic of Cameroon? Proceeding from the result of the plebiscite, the KNDP (Kamerun National Democratic Party) led by John Ngu Foncha won the elections with 233.571 votes, defeating the CPNC (Cameroon Peoples National Congress) with 97,741 votes. This victory meant that British Southern Cameroon was to secede from Nigeria, form an integral government with French Cameroon through constitutional auspices with Ahmadou Ahidjo as president of both Cameroons on October 1961 (Pungong, 1993).

This demonstrates the people's nature as being very critical and wise for they knew that joining any of these nations already created and whom have attained their autonomous independence will make live with an inferiority complex as a people with different cultures, customary practices and ancestors will be difficult to cope. Reason why the subsequent chapter will further analyze the effects of this choice made after many year of integration, had it been they were granted independence as an autonomous state without any integration neither with East Cameroon or Nigeria. Moreover, it is important to point out the relevance of such a historical issue and its correlation to this paper problem being the Anglophone demands in Cameroon. The Cameroon people through a "Pan- kamerun" nationalist idea were born with a good number of internal and external factors that paved the way for the fight of Cameroon's independence and reunification. It should be noted that, this was the most crucial period in Cameroon history, for it has shaped the nature and form of the Cameroon present state of politics through this joint fight and reunification by the two sovereign nations whom today feel many differences than similarities in all aspects which is today called the Anglophone problem.

After the successful granting of independence of the territory in 1961, there came over a number of real issues to be solved, for the unifications questions on either seceding ${ }^{1}$ or joining Nigeria were the beginning of the vital issues to be solved, while others issues like post independence factors were also supposed to be handled accordingly. Taking into consideration that a people of common ancestors but of different colonial heritage and culture was the reality of the day, the two joined states had to come to a consensus on an effective language policy for the country so that each of the joined people, English and French Cameroon would not be alienated. In the domain of culture, both cultures had to be blended from the inherited Anglo-French systems incorporated

${ }^{1}$ Separating 
in the political, judicial and educational systems. This meant that all political issues, judiciary issues and the education in the entire country had to be personified with existence of the two different languages and cultures. All official documents, offices and jurisdiction had to be embedded taking each of the above various cultures, whereby it would be impossible for a single educational system to exist to the detriment of another, for an Anglo-Saxon ${ }^{1}$ education was the reality adopted, confirmed and ratified (Chumbow, 1980). But the essential question as related to the topic of this piece of work is; is that the case today? The Anglophones contemporary demands are the simplest respond to this question as will be deeply analyzed in the subsequent topics.

\section{Emergence of the Anglophones Demands}

In this section, I will describe the various issues that have caused the emergence of the Anglophone grievances after a long period of union and what the immediate causes of the current crisis are. This chapter will explain all the demands made and problems faced by the Anglophone minority, demonstrating with concrete examples and perspectives that the need for self affirmation and determination was supposed to be the order of the day since from the beginning of the question of either joining Nigeria or East Cameroon in 1961. Some of these demands are issues of development in the Anglophone regions. Good developmental projects are not programmed for the Anglophone section of the country leaving the region underdeveloped. Another demand is the use of the two official languages. English language is one of the official languages but French is more important than English in every sphere in the country.

Also, disrespect of the Foumban constitutional conference which outlined how the union between English and French Cameroon will take place and how they will be governed, but to what extent are these clauses respected, bribery and corruption and lastly the long reign of president Paul Biya without any possible transition of central power to an Anglophone as president of the country (Njeuma, 1963).

Hale (2014) emphasizes that in the international perspective, Cameroon is usually described as one of the most peaceful countries in Africa, which has experienced little or no serious uprisings and has been able to maintain a certain level of stability in the sub region. Though plagued by Boko Haram activities, which has led to the death of many people and caused issues of insecurity especially in the northern part of Cameroon, political and civic order has been the order of the day in most cities in Cameroon. Hale (2014) explains that, looking at the present situation, it can be said that Cameroon has never witnessed such degree of instability with the present neglected Anglophone demands, which, if not taken seriously, could escalate to a civil war as its symptoms so far are very clear and visible. Some of the symptoms are the migration of people from the Anglophone regions to that of the Francophone regions and Nigeria. According to the United Nations report, 20,000 Cameroonians have sought refuge in Nigeria and about 160,000 people have been displaced for security reasons from the separatist and independent Anglophone community called Ambazonia ${ }^{2}$. Furthermore, according to International Crisis Group, about 163 people died including members of the security forces as a result of this crisis in 2016. This piece of research work is therefore consecrated towards a consistent contribution in creating awareness and demonstrating the extreme level at which the Anglophones are determined for their demands to be taken into serious consideration through two suitable possible means; federalism or secession and nothing else. Some of the prominent pressure groups are Southern Cameroon National Council, Ambazonia group, which is the most serious and determined, Cameroon Anglophone movement and Southern Cameroons People Organization who all have different mechanism of operation as some promulgate peaceful demonstrations and others the use of coercion if necessary.

\section{Anglophone Cameroons' Grievances}

Because of the foregoing, a number of problems emerged which gradually degenerated in to the present Anglophone crisis. Proceeding from the union with French Cameroon, several differences started emerging and as time went on, those differences and grievances started emerging into what is termed today the Anglophone crisis. Taking a closer look at this Anglophone crisis, in the subsequent paragraphs, I will discuss a few remote and immediate causes of this Anglophone demands today.

\section{Breach of some clauses of the Foumban constitutional conference}

From 17 to 21 July 1961, the political leaders of the young independent state, Eastern Cameroon, and their counterparts from Southern Cameroon met in the capital of the present Noun Department to lay the foundations of the unitary state. It is almost certain that the day after the plebiscite of February 11, 1961, the idea of a summit at Foumban will be borne. Sultan Njimoluh Seidou being one of the few dignitaries present at Yaoundé airport, on March 3, when John Ngu Foncha arrived, to report on the conduct of the referendum and Five weeks later, between the $11^{\text {th }}$ and 13 April 1961, President Ahidjo, successively receives at the palace, Njoya Arouna and his

\footnotetext{
${ }^{1}$ another term for Old English

${ }^{2}$ Ambazonia, also known as Amba Land, is a self-declared state consisting of the Anglophone portions of Cameroon, which previously comprised Southern Cameroons.
} 
nephew Sultan Njimoluh Seidou. It is clear that during these interviews, it was a question of stopping certain practical modalities of the meeting of Foumban, which shall be analyzed and discussed in the following paragraphs. This was later on confirmed because, Yaoundé, which was the capital of Eastern Cameroon at the time addressed to the administrative authorities in place in Foumban, giving instructions relating to this event. The senior divisional officer of Noun at the time, a certain Jean Marcel Mengueme and Foumban divisional officer at the time, Emmanuel Njoya, was officially in charge to organize the meetings in Foumban. These must, among other things, solve the thorny issue of accommodation, catering and transportation of delegates and animation in the city during the six days of the conference (Ateki, 2017).

\section{Marginalization of Southern Cameroonians}

Following from the conclusions and agreements made at the Foumban conference that both states will have equal status, it has never been the case to a greater extent of the southern Cameroonian are considered as the minority, better still second class citizens as it could be seen at every level of the government be it in the legislatives, the judiciary and the executives prior to the Anglophone crisis. For any national matters, French Cameroon is always given preferential treatments to the detriment of meritocracy and status quo. Due to this perpetual situation and marginalization, the Anglophones decided to speak up and fight for their rights, hence the Anglophone problem (Dicklitch, 2011).

\section{Lack of developmental projects in Southern Cameroon}

According to Africa Infrastructure Country Diagnostic (2011), Southern Cameroon which constitutes more than $60 \%$ of the country's GDP is the least developed part of the entire territory even though the smallest part of the entire territory in terms if size, yet the region is still not developed. The deplorable state of road in major cities such as Bamenda and Kumba has made Southern Cameroonians show their rage in what is today termed the Anglophone crisis. Schools, hospitals and other social amenities are greatly inadequate and deplorable causing a serious call of concern of the Anglophone.

\section{Brutalizing and molestation of Anglophone lawyers, teachers and students}

After several attempts by the Anglophones students to get solutions to their demands to no avail, the students decided to do a peaceful demonstration in 2016, for the student were protesting a two years' unpaid scholarship and a 20 United States Dollars late registration fee. In this regards, forces of law were sent to quench the demonstration but through unconstitutional means, using force. University students in a bid to support and join the riot processes of their several requests were held and severely beaten and arrested. On November 28, the crisis previously contained in the Northwest spreads to the Southwest. Students from Buea ${ }^{1}$ University organize a peaceful march on the campus to claim the payment of the award of excellence of the Head of State, dedicated students, denounce the ban in 2012 of the University of Buea Student Union (UBSU), and protest against the introduction of a penalty in case of late payment tuition fees and additional fees to view exam results (BBC Africa, $15^{\text {th }}$ November 2016).

The violent situation of 28 November in Buea and 8 December 2016, in Bamenda contributes to the aggravation and propagation via media platforms of this crisis. Images of bursts of forces were spreading rapidly over the Internet and were going around TV channels and international news. Between October 2016 and February 2017 , at least nine people were killed and more injured by gunshots. Close to 82 people were arrested including journalists and lawyers according to the minister of Communication, nearly 150 people, according to the Social Democratic Front ${ }^{2}$ were judged by a military court under the provisions of the Anti-Terrorism Act. Arrests and intimidation of English-speaking personalities also took place, such as the arrest without warrant even though benefiting of immunity as a magistrate of the Supreme Court, in March of Paul Abine Ayah, Supreme Court judge, charged with funding of the Anglophone mobilization (BBC Africa, $15^{\text {th }}$ December 2016).

\section{Underdevelopment of Southwest and Northwest regions of Cameroon}

According to Ebolo (2012), Southern Cameroon happens to be blessed with most of the country's natural resources; oil, forestry, fertile soils and waterfalls are some of the resources massively exploited and exported to foreign countries with little or no development in these regions. It is important to point out as well that; the Southwest region covers $25,410 \mathrm{~km} 2$ and represents approximately $5.43 \%$ of the total area of $475,442 \mathrm{~km} 2$. A survey of the National Institute of Statistics, conducted in early 2010 among economic actors in the country, $16.7 \%$ of chiefs surveyed companies found that the Southwest had a favorable business climate. This part of the country was ahead of Douala and Yaoundé since it is the region of Adamawa ${ }^{3}$, which presented itself as the

\footnotetext{
${ }^{1}$ is the capital of the Southwest Region of Cameroon. The town is located on the eastern slopes of Mount Cameroon

${ }^{2}$ Main opposition political party in cameroon

${ }^{3}$ The Adamawa Region (French: Région de l'Adamaoua) is a constituent region of the Republic of Cameroon. It borders the Centre and East regions to the south, the Northwest and West regions to the southwest, Nigeria to the west, the Central African Republic (CAR) to
} 
second choice of the heads of companies settled in Cameroon. Only $25 \%$ of investors found this climate unfavorable. Again, this was one of the best scores from this NIS survey. This favorable business climate in the Southwest encompasses its neighboring North West region. With its 17,300 km2, the NIS study on "The state of Cameroon's industry" shows that $57.1 \%$ of business leaders find that the business climate is "good enough" in the region. North West. In this category, the North West occupies the rank of favorable votes at the national level (Ebolo, 2012).

According to IMF (2015), with 22,000 job positions, the Cameroon Development Corporation (CDC) is the largest employer after the state. The region of South-West, proportionately guarded, is the one that absorbs the most workers in the private sector in Cameroon. It is certainly a colonial legacy set up in 1947 under the tutelage of Great Britain. In addition to the Cameroon Development Corporation (CDC), which has several oil palm, rubber and banana plants and plantations in the South West region, the region's economy has turnovers from the presence of the National Refining Company (SONARA), which is specialized in dealing with most of the country's petroleum needs. In addition, there was a high potential for the Nigerian Bakassi peninsula to be handed over to Cameroon on August 14, 2008. Tourism is also a potential source of considerable foreign exchange and employment for the population. Even if the trend towards the reduction of unemployment is $40 \%$ to $2 \%$ between 2001 and 2007 , the reduction of visible underemployment to less than $50 \%$ by 2020 seems difficult to achieve.

On a consensus of 1,150 billion FCFA for the public investment budget in 2015, for example, the two English-speaking regions of Cameroon were not the best of compared to other regions of the country. The Center is the lion's share with 157, 6 billion FCFA, the Littoral 105.9 billion, the South 99, 053 billion, the East more than 70 billion, the Far North 45, 43 billion FCFA, the South -Ouest with 34, 501171 billion FCFA, the West with 33, 212914 billion FCFA, the North-West with 25,146,224 billion FCFA, the Adamawa with 16, 069,404 billion FCFA and the North region 15, 698,725 billion FCFA. In 2013, the BIP of the North West Region was approximately 19.6 billion FCFA, of which 13.6 billion $(69 \%)$ were managed by the central services, while the allocation in 2014 was about 19 billion, 3 billion CFA francs, with about 12.7 billion (66\%) managed by the central services. Regarding revenue, between 2013 and 2014, the revenue of the Control and Anti-corruption Brigades of the Trade delegations decreased significantly between 2013 and 2014, from CFAF 27.5 million to CFAF 26.6 million, while those of the customs services have fallen considerably over the same period, from CFAF 217.5 million to CFAF 179.6 million (Kindzeka, 2016).

\section{The need for a return to Federalism}

According to the separatists who claim the proclamation of a new state called "Ambazonia" (etymologically meaning the Ambas bay of Cameroon) that is situated in the South west of Cameroon, Anglophones demand a return to federalism that prevailed in the country between 1961 and 1972, with two states within the same Republic, but this is far from being accepted by the central government in Yaoundé ${ }^{1}$, denying this request for federation. While the executive opposes a plea of inadmissibility to these two claims; secession and federalism, the climate has tightened in recent days until present. According to Amnesty International, 17 people were killed by security forces on the sidelines of demonstrations on Sunday 1 October 2016 and in several English-speaking cities especially Bamenda ${ }^{2}$ and Buea with the main motive, a return to federalism or secession with La Republique du Cameroun (Francophone). Authorities in the South West Anglophone region of Cameroon announced a press release on Thursday 28th September 2017 to ban traveling activities strictly so as to quench down the violent movements orchestrated as the argument of force through public demonstrations. It was also initiated in the region of the Northwest, where a state of emergency had been declared in these regions, before a symbolic so called "proclamation" of independence by English-speaking separatists on October 1 1, 2017. Closing of territorial and maritime borders, suspension of transport, prohibition to move between localities and prohibition of meetings of more than four persons in the public space, the severe measures announced by the authorities of the South-West took effect on Friday, September 30th at 9 o'clock which will end on $2^{\text {nd }}$ October at $7 \mathrm{am}$, according to the press release were all mechanisms to obstruct any return to Federalism nor secession by whatsoever means (Konings, 1996).

\section{Shutdown of School and Business Activities, Territorial and Maritime Borders to Anglophone Regions}

Furthermore, in reply to this measure by the government, the Anglophone rioters had to embark as well in a change of tactics as they had to shut down schools, accompanied by the support of the teachers who felt that the government had gone too far. It should be noted as well that during the manifestations at the University of Buea

the east, and the North Region to the north

${ }^{1}$ Yaoundé is the capital of Cameroon and, with a population of more than 2.8 million, the second-largest city in the country after the port city Douala

${ }^{2}$ Bamenda, also known as Abakwa and Mankon Town, is a city in northwestern Cameroon and capital of the Northwest Region 
through UBSU ${ }^{1}$, and SYNES, University lecturer's association members were arrested like Fontem Neba and Agbor Balla, all professors of the University of Buea. They were arrested on the basis that they are main leaders perpetrating the Anglophone revolts at the university levels. While its leader, Barrister Agbor Balla was still detained in Yaoundé pending trial, the consortium of the civil society of English-speaking Cameroon did not disarm itself, taking into consideration that Cameroonian authorities had taken the situation to an extreme level. They called on for continuous operation ghost town every Monday and to continue the strike movement in Northwestern and Southwestern schools (International Crisis Group, August 2017).

The trial of the three leaders of the English-speaking protests, Barrister Agbor Balla, Fontem Neba and Mancho Bibissi was later on postponed until 23 March. Pending the hearing before the military court of Yaoundé, the consortium of civil society in English-speaking Cameroon intended to put pressure on the Cameroonian government for their released for they had not even been auditioned so as to know the cause for their arrests, this demonstrating the dependent nature of the ineffective Cameroonian judiciary system. On Thursday, 23 February 2017, the organization called on the people of the North West and South West regions to continue their protests. The ghost town ${ }^{2}$ operations continued every Monday, as well as on special dates such as March 8 and May 20, as declared in the consortium statement (International Crisis Group, August 2017).

\section{Hosting of Meetings by the Central Government}

Following from the previous attempts made by the Anglophone activist in a bid to quench and change the fate of their marginalized situation, an exceptional security meeting was held on Friday, December 1, 2017 in Yaoundé, Cameroon, after a new attack which occurred in the night of Wednesday to Thursday, November 30, 2017 in the English-speaking area, in the Southwest region. Three people were killed, including two policemen, while an attack had already taken place the day before (RFI, published on the 1st Dec 2017).

\section{Effects of The Current Anglophone Crisis in Cameroon}

Since the dawn of time, all the wars of the world and all the crisis of humanity have always been settled around a negotiating table bringing together all the protagonists, even when there was the total defeat of one of the parties. Whatever is done and said, the Anglophone crisis will not escape this implacable logic of the inevitability of negotiation. The question that further comes in is, why then delay this salutary deadline if it is unavoidable anyway? Any additional delay in the convocation of the negotiation lengthens the list of the early deaths, compatriots mowed in this useless war, voluntarily provoked, therefore avoidable.

Moreover, another preliminary effect of the crisis is that it led to the call of attention of other international bodies and actors. This was as a result of the various injustices committed in the various regions and the defy of human rights. One month later after the outbreak of the crisis precisely on the 28th November 2016, the US State department passed on a pronouncement requesting the central government of Cameroon to resolve the situations and the tensions taking place so as to respect human rights. Following from this important visits due to the cries for the Anglophones towards the international arena asking for help, on December 2016, the United Nations Centre for Human Rights and Democracy in Central Africa condemned the ruthlessness and asked Cameroon regime to respect minority rights.

On the 18th January the following year, the president of the African Union Commission conveyed his concerns about actions of violence committed by the arm forces, arbitrary arrests, internments and called on the government to seek discourse with the representatives of the Anglophone leaders who instigated these strikes. The United Nations Special Representative for Central Africa visited Yaoundé on February and April successively as a call for concern with the on goings that led to the death innocent people in the course of this crux. He ensured a certain number of meetings as he met with Consortium leaders whom were imprisoned without trials and signed a pronouncement requesting the release of prisoners and the restoration of Internet connections in these two regions and preached the importance of dialogue in such delicate situation (International Crisis Group, August 2017).

This present crisis has resulted to a devastating situation with a lot of refugees who live in poor and deplorable conditions for some of them closer to Nigeria like those who lived in the capital city of Many Division, Mamfe ${ }^{3}$ moved to neighboring Nigeria not far from the Cameroon borders with Nigeria where they acquired protection.

After the wave of violence during the Anglophone crisis, some localities in a few states of Nigeria, especially in Cross River State, became refugee centers. In these places, the refugees far from their territory of origin were confronted with very deplorable living conditions such as the absence of drinking water, food and lived in unhygienic conditions as an impact to this crisis, which the government has remained silent to.

\footnotetext{
${ }^{1}$ University of Buea Students Union

${ }^{2}$ A ghost town is an abandoned village, town, or city, usually one that contains substantial visible remains

${ }^{3}$ Mamfe or Mamfé is a city in and the capital of Manyu, a division of the Southwest Region in Cameroon.
} 


\section{CONCLUSION}

Conclusively, according to my findings, the crisis emanated from a flawed and non regimented Foumban conference that was not strictly put in place as the constitution of 1961 promulgated; respect of English and French citizens with equal status. In the domain of language, English and French as the two official languages and the like. It is clear that after 57 years, a section of the Cameroon population notably Anglophones, are requesting a change and respect of the constitution as it was drafted and outlined for a peaceful union. Therefore, this chapter will be based on the possible outcomes of the crisis taking into consideration that it worsens day by day as time passes and the government is silent and impotent towards this bloody blitz taking the form of a civil war. Also, this chapter will establish the possible denouement of the upcoming elections of October 2018 with the present context of the crisis that is taking place in Cameroon, in the Anglophone regions. Ultimately, the end of this chapter will be much more focused on the aftermath of this current crisis and the future of the Anglophones in Cameroon.

It is very clear before negotiations are set forth, the lack of trust and the envy to elaborate possible negotiations with the central government taking into consideration their indulgent attitudes made the credibility of the ad hoc ${ }^{1}$ commission to be doubtful of its success. The first thing that was wrong with this commission was the fact that it constituted much more of Francophone than Anglophones who are the complainants. Their demands were up to 25 in number but Anglophone representatives did not see the possibility of this gathering to attain its objectives thus even 21 of the demands out of all the 25 demands posited. This made them to think of an alternative option, thus the restoration of federalism so as to ensure that all request are perfectly implemented but the government saw this as impossible.

Today, opinions on the form of the state, issued by professional organizations and associations of civil society now claiming public citizens of Southern Cameroons or Ambazonia, are divided. For the regime in place, Cameroon is united and indivisible though the constitution is not fully respected; for the government, there is no question of touching the shape of the centralized unitary state. For them, to return to federalism is to open the door to secessionism, which they strongly believed is the people's choice. Others emphasize the importance of federalism, bringing hope for democracy, good governance and development especially for the Anglophone region, which has been abandoned to Anglophones with little, or inadequate developmental projects being declared for these two rich and potentially vital sections of the country.

Having made a comprehensive analysis of the current Anglophone crisis that has plagued Cameroon in general, though the activities of this crisis were not encompassing the entire territory, it is clear that it had serious repercussions on the entire territory. In the subsequent paragraphs in guise of conclusion, it will be important to outline the possible outcomes of the current Anglophone crisis, an analysis of the upcoming October 2018 presidential elections and the future of Anglophones as a result of this self affirmation and demand for a general amendment of the present political, economic and social system that has plagued the two regions for long.

However, analyzing the encompassing nature of Cameroon's Anglophone crisis, several shortcomings were encountered with possibilities of visiting the interior parts of Southwest region highly affected by this crisis, insufficient material details explaining the solutions that would be adopted due to the unwilling nature of the government to cooperate with the federalist and secessionist. Also, this thesis expatiates how the crisis started with the partition of Cameroon in 1916 after the end of the First World War with the sharing of Cameroon into two between Britain and France as analyzed above. It is clear that following from this crucial event in Cameroon's history. Furthermore, Cameroon gained its independence and later on was confronted with reunifying the two Cameroon as one as it used to be in the 1880 's. This period constituted of the colonial period, Independence and Reunification.

Briefly, the history of Cameroon shaped what is today called the Anglophone crisis which is a crisis that was well predicted by some Cameroonian scholars perceiving the inequalities and disrespect of the constitution, thus explaining the demands made today in 2018. This thesis as well makes mention of the complete evolution of the crisis to its present situation, were little attacks and manifestations are still perpetrated especially in the Anglophone areas inadequate and palpable decisions taken by the head of state. Moreover, important topics like the role of this crisis and the $7^{\text {th }}$ October 2018 presidential and parliamentary elections are vital topics that could not be treated in this research work but are highly encouraged to research on as well.

Huge abstention and violence on Sunday 7th October 2018 marked the presidential election in the Englishspeaking South West and North West regions of Cameroon where armed separatists had announced their intention to prevent the vote. In Buea, the English-speaking South-West capital, surrounded by imposing security forces, the polling stations were deserted throughout the day, people were afraid to move out of their homes to exercise their civic right of voting.

In the South West regions, the 25,000 polling stations had opened at 08:00 AM, the diffusion of electoral tendencies was forbidden in Cameroon and the results were not expected for at least a week. The Constitutional

\footnotetext{
${ }^{1}$ Created or done for a particular purpose as necessary
} 
Council has two weeks legally to proclaim them. According to Hans de Marie Heungoup, a researcher with the International Crisis Group (ICG), "almost all the returns we receive place the participation rate below 5\%" In the English-speaking regions of South-West and North-West where more 300,000 people had to flee their homes. This very low participation illustrates that the armed separatists group have gained influence on these two regions. This simply expresses the symbolic break between part of the English-speaking population and the Republic of Cameroon, many polling stations could not be set up in villages in these regions for fear of separatist attacks (La Croix, 07 October 2018).

More than 175 members of the Cameroonian defense and security forces were killed in the conflict in the English-speaking zone, as well as more than 400 civilians, according to NGOs. No record is available on the separatist side. In the Far-North region, the army was also deployed to fight the jihadists of Boko Haram who launched repeated attacks since 2014 on the Cameroonian populations. Before the vote and for the first time since the 1992 presidential election, two strong opponents joined forces against Paul Biya: Akere Muna and Maurice Kamto of the Cameroon Renaissance Movement (CRM).

Elections Cameroon (Elecam), the body that organizes the election, however, refused that the ballots bearing Mr. Muna's name be removed for the benefit of Mr. Kamto, considering that his withdrawal of his candidacy on Friday eve 6th October 2017 was too late and was not provided by law. Two other candidates could expect a significant score: Joshua Osih, candidate of the Social Democratic Front (SDF, main opposition party) and Cabral Libii, the youngest of the election at 38, who has strongly mobilized in its meetings were all defeated by the main party in power since 1982, the Cameroon's People's Democratic Movement (CPDM) ${ }^{1}$, with president Paul Biya at the head of the party and natural candidate since 1987 presidential elections until now 2018 elections (La Croix, 07 October 2018).

\section{REFERENCES}

Ardener, S. Eye-Witnesses to the Annexation of Cameroon 1883-1887, Buea.

Ardener, Shirley G (1968), Eye-Witness to the Annexation of Cameroon, 1883-1887, Buea, Government Press. Atanga, MA (2011), The Anglophone Cameroon Predicament, African Books Collection, Cameroon.

Dejo, (2017), 'Is federalism bringing hope ?: Case of Cameroon'Economic Policies at Nkafu Policy Institute, viewed 16 July 2018, <http://www.foretiafoundation.org/wp-content/uploads/2017/05/Article_leF\%C3\%A9d\%C3\%A9ralisme_Gaelle_edited_020517.pdf $>$

Elango, Lovett Z. (1987), The Anglo-French Condominium in Cameroon, 1914-1916: History of A Misunderstanding, Limbe: Navi Group Publication.

Elong, EE (2012), 'Sovereignty In the Making: The Case of Anglophone Cameroon', proceedings of the conference workshop on sovereignty in the making, Vrije Universiteit Brussel, University of Oslo, PP. 4-6.

Fanso, V. G. (1989), Cameroon History for Secondary Schools and Colleges, Volume 2: The Colonial and Post Colonial Period, London: Macmillan Publishers Limited.

Halle, HE (2014), The Force of Argument' and the Fight for an Anglophone Identity in Cameroon, University of Maryland Francis King Carey School of Law, Maryland.

International Crisis Group, (2017) “Cameroon's Anglophone Crisis at the crossroads, August 2017.

Konings (1990), 'The Anglophone problem in Cameroon in the 1990s.' Afrika-Stdiecentrum Leiden, viewed 15 July 2018, <http://www.politique-africaine.com/numeros/pdf/062025.pdf>

La Croix viewed 9 January 2019, < https://www.jeuneafrique.com/639943/politique/presidentielle-aucameroun-le-vote-impossible-des-deplaces-de-la-crise-anglophone/>

Ngoh, V. J. (1996) History of Cameroon Since 1800, Limbe, Malawi: Presbook.

Nkoyock, AN (2017), 'English crisis in Cameroon: does federalism bring hope?' Jeune Afrique, Viewed 17 July 2018, <http://www.jeuneafrique.com/396895/politique/crise-anglophone-cameroun-federalisme-porteurdespoir/>.

Osuntokun, J. (1974), “Administration \& Franco-British Rivalry in the Cameroons, Sept. 1914, to March 1916," paper presented at a seminar, University of Ibadan.

Pungong, Victor P. (1993), "United Nations in the Political Evolution of Cameroon (From Trusteeship to Reunification, 1946 -1961)," Unpublished PhD Thesis, Jesus College, University of Cambridge.

RFI Afrique (2018), Viewed 17 July 2018, < http://www.rfi.fr/afrique/20180624-cameroun-crise-anglophoneregain-tension-bamenda>.

RFI Afrique (2018), Viewed 6 November 2018, <http://en.rfi.fr/africa/20110926-campaign-presidentialelections-kicked-cameroon>

Robinson, R., Gallagher, J., \& Denny, A. (1961). Africa and the Victorians: The Climax of Imperialism in the Dark Continent. New York, NY: St. Martin's Press.

The Southern Cameroons National Council (SCNC) (1995), “The London Communiqué", Issued by the

${ }^{1}$ Political party in power presently 
Delegation of the Southern Cameroons following their Mission to the United Nations in May/June 1995 to File a Petition against the Annexation of the Southern Cameroon by La République du Cameroun.

Transparency International, (2011) Corruption Perceptions Index, CPI.

Victor, TL (1964), The Cameroon, from Mandate to Independence, University of California press, California. 